\title{
朝倉地域に産する周防変成岩類の接触変成作用の温度圧力条件一上昇過程の 制約一
}

Pressure and temperature conditions of contact metamorphism of the Suo metamorphic rocks in Asakura area, Fukuoka Prefecture, Japan: constraints on uplifting process

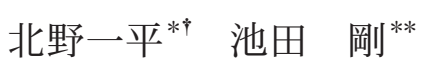

Ippei Kitano $^{* \dagger}$ and Takeshi Ikeda ${ }^{* *}$

2012 年 2 月 24 日受付.

2012 年 8 月 21 日受理.

九州大学理学部地球惑星科学科

Department of Earth and Planetary Sciences, Faculty of Science, Kyushu University, 33 Hakozaki, Fukuoka 812-8581, Japan 現所属：九州大学大学院比較社会文化学府日本 社会文化専攻地域資料情報講座

present address: Division of Regional Material Information, Graduate School of Social and Cultural Studies, Kyushu University, 744 Motooka, Nishi-ku, Fukuoka 819-0395, Japan

** 九州大学大学院理学府地球惑星科学部門

Department of Earth and Planetary Sciences, Graduate School of Science, Kyushu University, 33 Hakozaki, Fukuoka 812-8581, Japan

Corresponding author; I. Kitano,

2CS12010E@s.kyushu-u.ac.jp

\begin{abstract}
The Suo metamorphic rocks of the Asakura area of Fukuoka Prefecture underwent contact metamorphism during the intrusion of granitic magmas in the Cretaceous, forming a contact aureole. This aureole is divided from south to north with ascending metamorphic grade into chlorite, chlorite-biotite, biotite, and andalusite zones, based on pelitic mineral assemblages. The andalusite isograd is defined by a muscovite + quartz $=$ andalusite + K-feldspar + water reaction, based on the coexistence of andalusite and K-feldspar. Garnet-biotite thermometry and garnet-biotite-plagioclase-quartz barometry indicate that the andalusite zone formed at temperatures of $560 \pm 50{ }^{\circ} \mathrm{C}$ and at pressures of $2.3 \pm 0.90 \mathrm{kbar}$. The Suo metamorphic rocks were exhumed to ca. $9 \mathrm{~km}$ depth by around $95 \mathrm{Ma}$, assuming that heat was supplied from the Asakura granodiorite to the north, and reached the surface and were overlain by sediments of the Nogata Group sometime before 44 Ma.
\end{abstract}

Keywords: Suo metamorphic rocks, contact metamorphism, pressure and temperature condition, Asakura area

\section{はじめに}

三郡変成帯は Nishimura(1998) により，変成年代や変成 条件で蓮華帯と周防帯に分けられている。蓮華帯は330～ $280 \mathrm{Ma}$ に青色片岩相から緑策石一角閃岩相の変成作用を受 けた変成帯であり, 飛騨外縁帯から山陰地方を経て北部九州 まで広がっている. 周防帯は 230〜 $160 \mathrm{Ma}$ にプレーナイト 一青色片岩相，まれに緑笠石一角閃岩相の変成作用を受けた 変成帯であり, 近畿地方西部から中国地方を経て北部および 中部九州, 長崎, 西表島および石垣島まで広がっている (Nishimura, 1998)。蓮華帯と周防帯の一部は，主に白亜 紀花崗岩類の貫入による接触変成作用を受けている (井上, 1957; 村上・藤本, 1957; 山田, 1972; 佐脇, 1985; Fukuyama et al., 2004; 富田ほか, 2008)。 そのうち, 周防帯の 泥質の接触変成岩中では, 低圧で安定な紅柱石や董青石など の産出が報告され(村上・藤本, 1957; 佐脇, 1985; 富田ほか, 2008)，周防帯は地下浅所で花崗岩類に貫入されたことがわ かる. この深さは接触変成作用の温度圧力条件から求めるこ とができる.

本研究では冷却年代が既知の花崗岩類による接触変成作用
を受けた，福岡県朝倉地域に産する周防変成岩類(Nishimura, 1998)の変成分帯を行つた. そして, 接触変成作用の 温度圧力条件を見積もつた. 白亜紀に接触変成作用を被つた 北部九州の周防帯の変成条件の研究と比較することにより, 接触変成作用時の周防変成岩類の深さ分布を考察した.

\section{地 質 概 説}

研究地域には東西に約 $20 \mathrm{~km}$ ，南北に約 $15 \mathrm{~km}$ にわたり 周防変成岩類が分布している. その北部と南東部は白亜紀花 崗岩類に貫入されている. 東部は古第三系直方層群と新第三 系北坂本累層に覆われ, 西部から南部にかけては第四系に覆 われている(井上, 1957; 松本, 1958）（Fig. 1).

研究地域は全体としてドーム構造を形成している (井上, 1957). ドームの北翼部は小褶曲がなく, 北上するにつれて 北向きに急傾斜 $\left(40^{\circ} \sim 70^{\circ}\right)$ となっている. ドームの南翼部 は小褶曲を繰り返しており，傾斜は北翼部に比べて緩やか (30以下)である. 線構造は一般的に ENE-WSW 方向で ある (井上, 1957). 断層には E-W 系と NE-SW 系があり, 前者は後者より先に形成されたと考えられている(井上, 1957). 

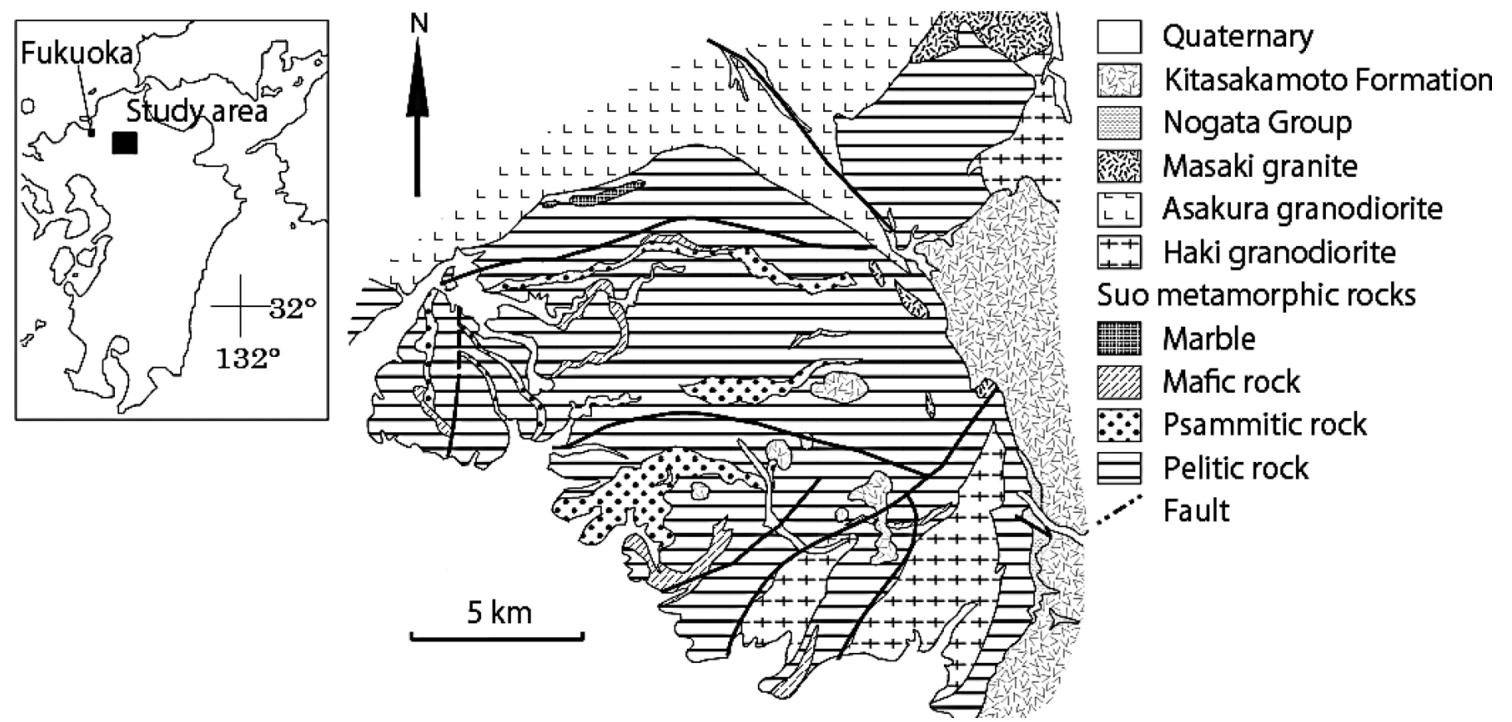

Fig. 1. Maps showing the location and geology of the Asakura area; after Inoue (1957) and Kubo et al. (1993).

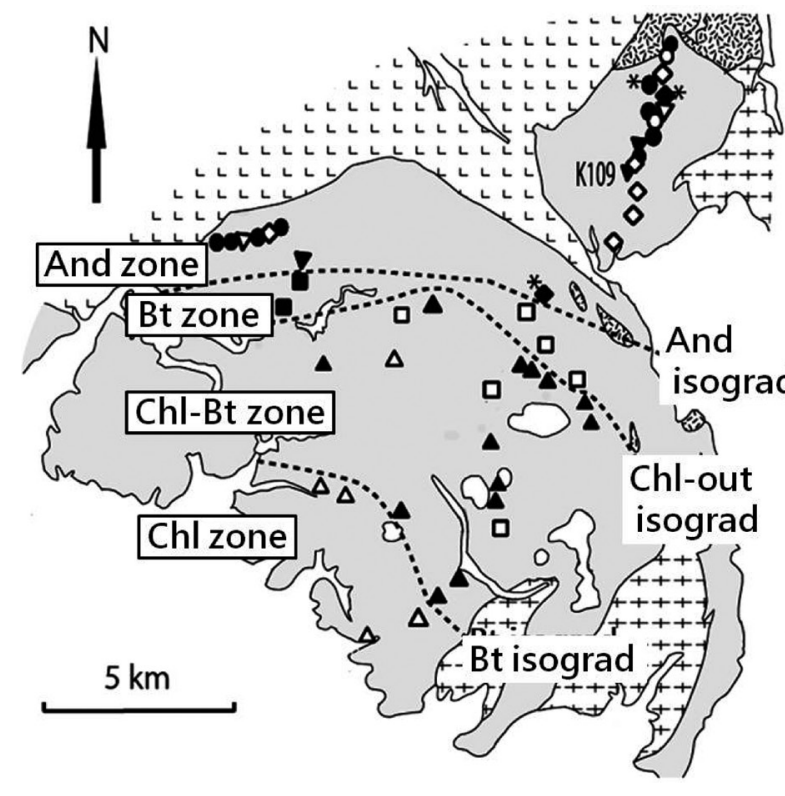

変成岩類は主に泥質岩からなり，その他に砂質岩，苦鉄質 岩, 珪質岩および結晶質石灰岩が産する(井上, 1957; 松本, 1958)，泥質岩は砂質岩，苦鉄質岩および結晶質石灰岩を挟 む. その中で厚さ 200〜300 m の層をなす砂質岩には薄層 の苦鉄質岩が産し，比較的厚い層 (約 $60 \mathrm{~m}$ ) をなす苦鉄質岩 には厚さ $1 \mathrm{~m}$ 以下の薄層の珪質岩が産する(井上, 1957). 井上 (1957) はこの地域の変成分帯を行い, 泥質岩や砂質岩 中に黒雲母が出現し, 同時に苦鉄質岩中にアクチノ閃石が出 現するアイソグラッド，および苦鉄質岩中に透輝石が出現す るアイソグラッドにより 3 帯に分けた.

本地域に産する花崗岩類は貫入関係より，古い順に杷木花 崗閃緑岩, 朝倉花崗閃緑岩および真崎花崗岩に分類される (唐木田ほか, 1962; 唐木田ほか, 1992)。このうち, 南東部 に貫入している杷木花崗閃緑岩の $\mathrm{Rb}-\mathrm{Sr}$ 全岩アイソクロン

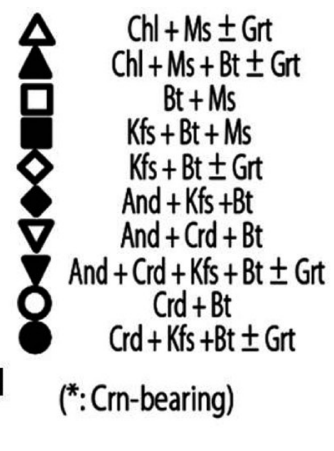

Quaternary and Tertiary

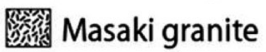

$\square$ Asakura granodiorite

\pm Haki granodiorite

$\square$ Metamorphic rocks

$\therefore$ Isograd
Fig. 2. Distribution of pelitic mineral assemblages, metamorphic zones, and the location of the sample analyzed in detail during this study (K109); all assemblages contain quartz (Qtz) and plagioclase (Pl), both of which are omitted in the legend. Abbreviations: Chl, chlorite; Ms, muscovite; $\mathrm{Bt}$, biotite; Grt, garnet; Crd,cordierite; Kfs, K-feldspar; And, andalusite; and Crn, corundum.
年代は $118 \pm 11.3 \mathrm{Ma}$ であり (小山内ほか, 1993), 北部に 貫入している朝倉花崗閃緑岩の黒雲母の $\mathrm{K}-\mathrm{Ar}$ 年代は 95.2 ェ4.8 Maである(村上, 1989). 松本 (1958)によれば, 杷木 花崗閃緑岩と朝倉花崗閃緑岩は変成岩類に対してそれぞれ subconcordant と concordant な貫入をしている.

東部に産する直方層群は石炭と凝灰質岩を頻繁に挟む泥 岩, 砂岩および碟岩からなる. 最上部層のデイサイト質凝灰 岩中のジルコンのフィッショントラック年代として $44.2 \pm$ 3.4 Ma が得られている(尾崎・濱崎, 1991)。直方層群を 覆つている北坂本累層は基底角碟岩と安山岩〜デイサイト質 溶岩, 凝灰角碩岩および火山冈碟岩からなる. ジルコンの フィッショントラック年代は凝灰角㗂岩から $5.66 \pm 0.30 \mathrm{Ma}$ が, 安山岩質溶岩から $4.83 \pm 0.51 \mathrm{Ma}$ が得られている(渡 辺ほか, 1986). 


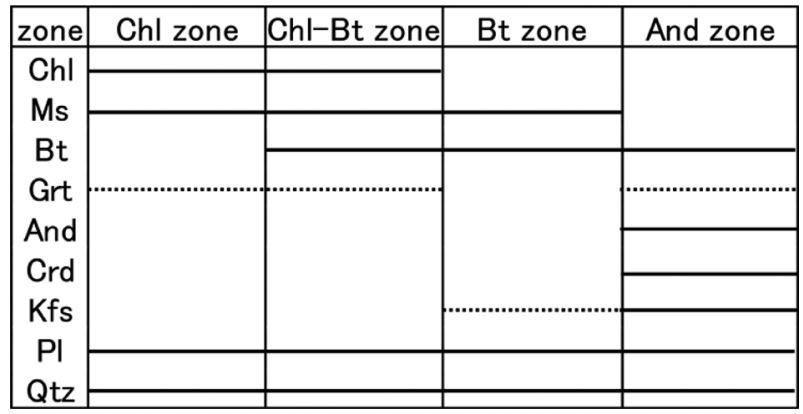

Fig. 3. Stability range of the constituent minerals within pelitic rocks in each zone; dotted lines indicate minor or rare minerals.

\section{変成 分 帯}

調查地域の広範囲に分布する泥質岩を用いて変成分帯を 行った. 南から北へ順次, 黒雲母が出現する黒雲母アイソグ ラッド, 緑泥石が消滅する緑泥石消滅アイソグラッド, 紅柱 石が出現する紅柱石アイソグラッドを定義した. この 3 つ のアイソグラッドによって, 調査地域は南から緑泥石帯, 緑 泥石一黒雲母帯, 黒雲母帯および紅柱石帯に分けられる. 変 成分帯と各鉱物組み合わせの分布を Fig. 2 に示す。各帯に おける泥質岩中の鉱物が安定な範囲と，各岩型の鉱物組み合 わせをそれぞれ Fig. 3, Table 1 に示す. 電気石, ジルコン, 方解石, スフェーン, 緑策石, 燐灰石, 炭質物, イルメナイ ト，黄鉄鉱は副成分鉱物として泥質岩中に含まれる.

\section{1. 緑泥石帯}

緑泥石帯は, 泥質岩中に黒雲母が含まれないことで定義さ れる. 主に緑泥石や白雲母からなる優黒質部と, 主に石英や 斜長石からなる優白質部が縞状構造をなす．緑泥石と白雲母 （ごちらも長軸長は最大約 $0.3 \mathrm{~mm}$ ) は, 定向配列して片理を
形成している (Fig. 4a). 白雲母と緑泥石からなる薄層が微 褶曲していることもある. ザクロ石は優黒質部に時折産し, 自形〜半自形で, 最大粒径が約 $0.2 \mathrm{~mm}$ になる. 通常, 包 有物を含まないが，一部炭質物を包有することがある．石英 はしばしば波動消光や縫合組織を示す、緑泥石はしばしば酸 化緑泥石になっている. 泥質岩の代表的な鈗物組み合わせ は, 緑泥石 + 白雲母である. 以下, 共通して含まれる斜長 石と石英は省略する.

\section{2. 緑泥石一黒雲母帯}

緑泥石一黒雲母帯は, 泥質岩中に黒雲母と緑泥石が共存す ることで定義される. 黒雲母 (最大約 $0.3 \mathrm{~mm}$ ) は主に優黒質 部に産し, 半自形 他形で緑泥石や白雲母とともに定向配列 して片理を形成している (Fig. 4b). この帯の緑泥石と白雲 母の最大の長軸長は, それぞれ約 $0.5 \mathrm{~mm}$, 約 $0.3 \mathrm{~mm}$ であ る. 黒雲母の一部はしばしば緑泥石に置き換えられている. この帯の高変成度域では, 低変成度域に比べて緑泥石の量が 少なく, 黒雲母の量が多い. 泥質岩の代表的な鉱物組み合わ せは, 緑泥石 + 白雲母 + 黒雲母と黒雲母 + 白雲母である.

\section{3. 黒雲母帯}

黒雲母帯は, 泥質岩中に緑泥石を欠くことで定義される. 黒雲母と白雲母は定向配列している (Fig. 4c). この帯の黒 雲母 (最大約 $0.4 \mathrm{~mm}$ ) と白雲母 (最大約 $0.7 \mathrm{~mm}$ ) は, 緑泥石 一黒雲母帯のそれらより粗粒である. まれに, 半自形〜他形 のカリ長石 (最大約 $0.5 \mathrm{~mm}$ ) が優白質部のみに産している. 石英の縫合組織は弱くなつている. 後退変成作用の産物と夕 られる, 細粒の白雲母が時折みられる. 泥質岩の代表的な鉱 物組み合わせは，黒雲母＋白雲母である.

\section{4. 紅柱石帯}

紅柱石帯は泥質岩中に広く紅柱石が産することで定義され る. 紅柱石は最大約 $2 \mathrm{~mm}$ の半自形〜他形の斑状変晶とし て産する (Fig. 4d). 黒雲母や白雲母, 石英, 不透明鉱物な どを包有している. また, 紅柱石帯には半自形〜他形の董青

Table 1. Pelitic, psammitic, mafic, and calc-silicate mineral assemblages within each metamorphic zone; abbreviations are as for Fig. 2 with the addition of Ep, epidote; Cam, calcic amphibole; Zo, zoisite; Cpx, clinopyroxene; Cal, calcite; and Spn, sphene.

\begin{tabular}{|c|c|c|c|c|}
\hline & Chl zone & Chl-Bt zone & Bt zone & And zone \\
\hline Pelitic rock & $\begin{array}{l}\mathrm{Chl}+\mathrm{Ms} \pm \mathrm{Grt}+\mathrm{Pl} \\
+\mathrm{Qtz}\end{array}$ & $\begin{array}{l}\mathrm{Chl}+\mathrm{Ms}+\mathrm{Bt} \pm \mathrm{Grt} \\
+\mathrm{Pl}+\mathrm{Qtz} \\
\mathrm{Bt}+\mathrm{Ms}+\mathrm{Pl}+\mathrm{Qtz} \\
\mathrm{Chl}+\mathrm{Ms}+\mathrm{Pl}+\mathrm{Qtz}\end{array}$ & $\begin{array}{l}\mathrm{Bt}+\mathrm{Ms} \pm \mathrm{Kfs}+\mathrm{Pl} \\
+\mathrm{Qtz}\end{array}$ & $\begin{array}{l}\mathrm{Bt}+\mathrm{Kfs} \pm \mathrm{Grt}+\mathrm{Pl} \\
+\mathrm{Qtz} \\
\mathrm{Bt}+\mathrm{Kfs}+\mathrm{And}+\mathrm{Pl} \\
+\mathrm{Qtz} \\
\mathrm{Bt}+\mathrm{And}+\mathrm{Crd}+\mathrm{Pl} \\
+\mathrm{Qtz} \\
\mathrm{Bt}+\mathrm{Kfs}+\mathrm{And} \\
+\mathrm{Crd} \pm \mathrm{Grt}+\mathrm{Pl} \\
+\mathrm{Qtz} \\
\mathrm{Bt}+\mathrm{Crd}+\mathrm{Pl}+\mathrm{Qtz} \\
\mathrm{Bt}+\mathrm{Kfs}+\mathrm{Crd} \\
\pm \mathrm{Grt}+\mathrm{Pl}+\mathrm{Qtz}\end{array}$ \\
\hline Psammitic rock & $\begin{array}{l}\mathrm{Chl}+\mathrm{Ms}+\mathrm{Kfs} \pm \mathrm{Pl} \\
+\mathrm{Qtz}\end{array}$ & $\begin{array}{l}\mathrm{Bt}+\mathrm{Ms}+\mathrm{Kfs} \pm \mathrm{Pl} \\
+\mathrm{Qtz}\end{array}$ & $\begin{array}{l}\mathrm{Bt}+\mathrm{Ms} \pm \mathrm{Grt}+\mathrm{Pl} \\
+\mathrm{Qtz}\end{array}$ & \\
\hline Mafic rock & $\begin{array}{l}\mathrm{Chl}+\mathrm{Ep} \pm \mathrm{Ms} \\
\pm \mathrm{Cam}+\mathrm{Pl}+\mathrm{Qtz}\end{array}$ & $\begin{array}{c}\mathrm{Ep}+\mathrm{Cam} \pm \mathrm{Chl} \\
+\mathrm{Pl}+\mathrm{Qtz}\end{array}$ & & $\begin{array}{c}\mathrm{Cpx}+\mathrm{Cam}+\mathrm{Bt} \\
\pm \mathrm{Zo}+\mathrm{Pl} \pm \mathrm{Qtz}\end{array}$ \\
\hline Calc-silicate rock & $\begin{array}{l}\mathrm{Chl}+\mathrm{Ms}+\mathrm{Ep} \\
\pm \mathrm{Cal} \pm \mathrm{Spn}+\mathrm{Pl} \\
+\mathrm{Qtz}\end{array}$ & $\begin{array}{l}\mathrm{Bt}+\mathrm{Chl}+\mathrm{Ms}+\mathrm{Ep} \\
\pm \mathrm{Cal} \pm \mathrm{Spn}+\mathrm{Pl} \\
+\mathrm{Qtz}\end{array}$ & $\begin{array}{l}\mathrm{Bt}+\mathrm{Ep}+\mathrm{Cam} \\
\pm \mathrm{Ms} \pm \mathrm{Cal} \pm \mathrm{Spn} \\
+\mathrm{Pl}+\mathrm{Qtz}\end{array}$ & \\
\hline
\end{tabular}





Fig. 4. Photomicrographs of representative pelitic rocks in each zone under plane polarized light, barring (g), which was taken under cross-polarized light. (a) Muscovite and chlorite have preferred orientations and define the schistosity in the chlorite zone. (b) Biotite often occurs parallel to the schistosity in the chlorite-biotite zone. (c) Biotite and muscovite have preferred orientations in the biotite zone. (d) Subhedral or anhedral porphyroblasts of andalusite are present in melanocratic sections of the andalusite zone; these porphyroblasts are often in contact with cordierite and biotite. (e) Andalusite locally rimmed by cordierite aggregates. (f) Garnet in the andalusite zone is euhedral to subhedral. (g) Corundum in the andalusite zone rimmed by muscovite aggregates. 


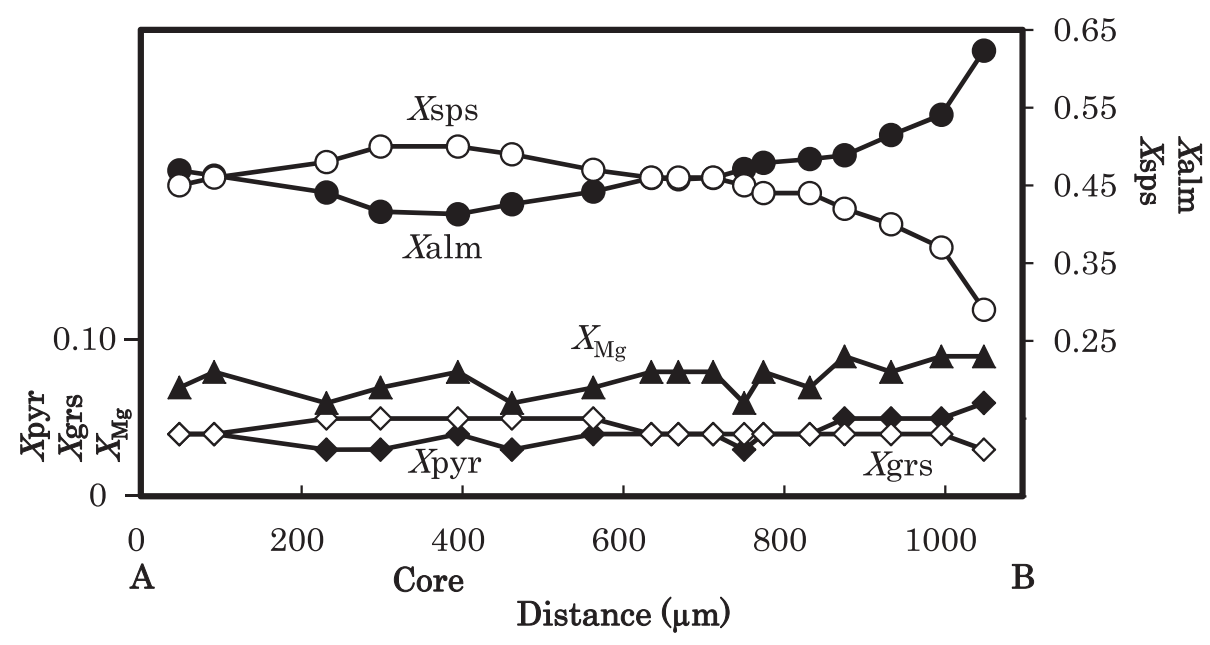

Fig. 5. Zoning profile of a garnet along line $A B$ in Fig. 4f, showing variations in almandine (Xalm : Total Fe / (Total Fe + Mg + Mn + Ca)), spessartine (Xsps: Mn / (Total $\mathrm{Fe}+\mathrm{Mg}+\mathrm{Mn}+\mathrm{Ca}))$, pyrope (Xpyr: $\mathrm{Mg} /$ (Total Fe $+\mathrm{Mg}+\mathrm{Mn}$ $+\mathrm{Ca})$ ), grossular (Xgrs: Ca / (Total Fe $+\mathrm{Mg}+\mathrm{Mn}+\mathrm{Ca}))$, and $X_{\mathrm{Mg}}$ $(=\mathrm{Mg} /($ Total $\mathrm{Fe}+\mathrm{Mg}))$ contents. Numbers represent mole fractions of the four end-member components and $X_{\mathrm{Mg}}$.

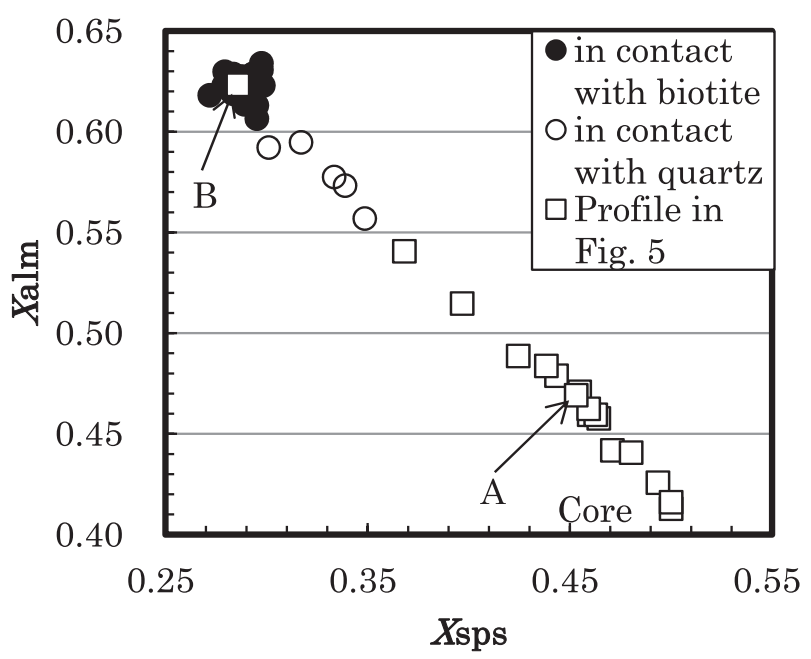

Fig. 6. Graph showing variations in $X$ alm vs. $X$ sps compositions shown in Fig. 5 and in the rims of several grains in contact with biotite or quartz; analyses labeled A and B indicate the rim composition at $\mathrm{A}$ and $\mathrm{B}$ in Fig. 5, respectively.

石がしばしば産し, 斑状変晶(最大約 $1.7 \mathrm{~mm}$ )をなすことが ある. 紅柱石を囲む堇青石の多結晶体がみとめられる (Fig. 4e). 黒雲母は長軸長最大約 $0.7 \mathrm{~mm}$ で, あまり定向配列し ていない. カリ長石は最大粒径約 $0.8 \mathrm{~mm}$ であり, 細粒の 白雲母や石英を包有している. 石英には波動消光や縫合組織 がほとんど見られない。ザクロ石は優黒質部と優白質部の両 方に産し，優黒質部で自形〜半自形に，優白質部で他形に なっている．粒径は最大約 $0.8 \mathrm{~mm}$ であり(Fig. 4f)，緑泥 石や石英，イルメナイトなどを包有する，堇青石はしばしば ピナイト化したり, 細粒の白雲母や黒雲母の集合体に一部あ るいは完全に置き換えられたりしている.

紅柱石帯の泥質岩にはまれにコランダムが産する. Fig. 2 に示すように，コランダムはカリ長石を含む泥質岩に限ら れ, そのコランダムは白雲母の多結晶体に囲まれている (Fig. $4 \mathrm{~g})$.

泥質岩の代表的な鉱物組み合わせは, 黒雲母 + カリ長石
+ 紅柱石, 黒雲母 + カリ長石 + 紅柱石 + 董青石および黒雲 母+カリ長石 + 堇青石である.

\section{鉱物の化学組成}

紅柱石帯の 1 試料(No. K109) 中の構成鉱物の化学組成を 測定した. 産地は Fig. 2 に示す. 鉱物組み合わせは, 黒雲 母 + カリ長石 + 紅柱石 + 堇青石 + ザクロ石で, 副成分鉱 物として電気石, 燐灰石, 炭質物, イルメナイト, 黄鉄鉱が 含まれる. 主に黒雲母, ザクロ石, 紅柱石, 堇青石からなる 優黒質部と, 主に石英, 斜長石, カリ長石からなる優白質部 からなる. 莱青石はピナイト化している. この試料を九州大 学のエネルギー分散型 EPMA (走査型電子顕微鏡 JEOL5800LVに Oxford Link ISIS を装着)を用いて, 照射 電流 $0.5 \mathrm{nA}$, 加速電圧 $20 \mathrm{kV}$, ビ一ム径 $4 \mu \mathrm{m}$ という条件 で測定した．測定時間 100 秒で，ZAF 補正を行った. Na はヒスイ輝石, $\mathrm{Mg}, \mathrm{Al}, \mathrm{Si}$ は酸化物, K は臭化カリウム, $\mathrm{Ca}$ はフッ化カルシウム, $\mathrm{Ti}, \mathrm{Mn}, \mathrm{Fe}$ は金属を各元素の標 準試料として用いた.

\section{1. ザクロ石}

ザクロ石は縁辺部に向かってスペッサルティン成分とグ ロッシュラー成分が減少し, アルマンディン成分とパイロー プ成分が増加する累帯構造を示す (Figs. 5, 7). $X_{\mathrm{Mg}}(=\mathrm{Mg} /$ $($ Total $\mathrm{Fe}+\mathrm{Mg}))$ はパイロープ成分と同様に, 縁辺部に向 かって増加する (Fig. 5)。しかし, 縁部の組成は同一でない (Fig. 5). この累帯構造の組成変化は一本のトレンドを形成 し (Fig. 6), 同一試料の他の縁部の組成もこのトレンド上に のる. アルマンディン成分とスペッサルティン成分は縁部で も場所ごとに異なる. このうち, 黒雲母に富む部分と接する 縁部は粒子によらずほぼ一定の組成を示し, そのトレンド上 でスペッサルティン成分の最小值をとる. 石英に富む部分と 接する縁部の組成はこのトレンド上でばらつく(Fig. 6).

\section{2. 黒雲母}

優黒質部の黒雲母は優白質部のものよりも $\mathrm{Ti}$ に富夕, 低 い $X_{\mathrm{Mg}}$ をもつ傾向がある (Fig. 8). 優黒質部の黒雲母でも, 董青石の分解によって生成されたと考えられる黒雲母は Ti に乏しく, 高い $X_{\mathrm{Mg}}$ をもつ(Fig. 8). 

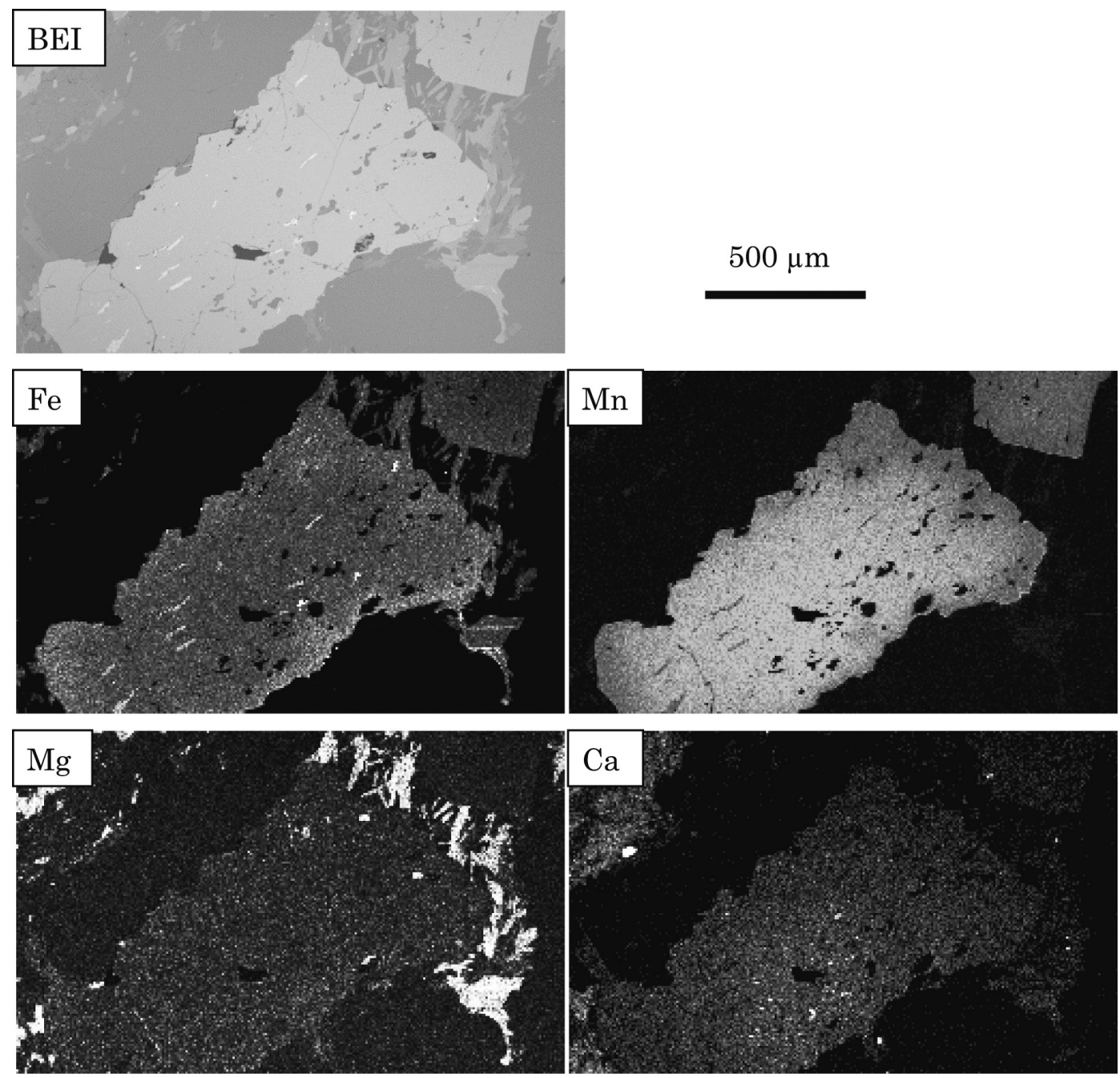

Fig. 7. Backscattered electron images (BEI) and X-ray image maps showing variations in $\mathrm{Fe}, \mathrm{Mn}, \mathrm{Mg}$ and $\mathrm{Ca}$ concentrations in the garnet shown in Fig. 4f.

\section{3. 斜長石}

斜長石は縁辺部に向かってアノーサイト含有量 $(=\mathrm{Ca} /$ $(\mathrm{Ca}+\mathrm{Na}+\mathrm{K}))$ が減少する累帯構造を示し, 核部の最大の アノーサイト含有量は優黒質部で 0.25 , 優白質部で 0.21 で ある. 優黒質部で, 縁部のアノーサイト含有量が 0.04 の斜 長石が局所的に産する.

\section{議}

\section{論}

\section{1. 変成反応}

泥質岩を用いた本研究の変成分帯は, 泥質岩, 砂質岩およ び苦鉄質岩を用いた井上 (1957)の変成分帯と次の点で異な る. 井上 (1957)の苦鉄質岩を用いたアイソグラッドは，本 研究では定義されなかった。 しかし, 透輝石が出現する地域 は紅柱石帯に限られている(Table 1)。井上(1957) は透輝石 の分布する地域を最高変成度域と定義しており，その分布は 本研究での紅柱石帯とほぼ一致する，本研究では，井上 (1957)に記載されていなかった紅柱石が広範囲に産するこ とを確認したので，紅柱石帯を定義した．最後に，井上
（1957）の黒雲母アイソグラッドより低変成度側で黒雲母を 確認したので, 黒雲母アイソグラッドはやや南西に再配置さ れた.

緑泥石带の砂質岩の主な鉱物組み合わせは, 緑泥石 + 白 雲母 + カリ長石で, 緑泥石一黒雲母帯の砂質岩のそれは, 黒 雲母 + 白雲母 + カリ長石である. 両者の間に

$$
\text { 緑泥石 }+ \text { カリ長石 }=\text { 黒雲母 }+ \text { 白雲母 }+ \text { 石英 }+ \text { 水 }
$$

の AKF 不連続反応が考えられる.これは Wang et al. (1986) が領家帯で, 砂質岩の黒雲母アイソグラッド反応と して定義した反応である. 本研究では砂質岩の産出が少ない こと, 砂質岩中の黒雲母が Wang et al. (1986)の記載のよ うなカリ長石を囲む組織が見られないことより, 泥質岩の黒 雲母アイソグラッド反応と反応 (1)の前後関係を野外で確認 することはできなかった. しかし, 泥質岩中で黒雲母は白雲 母, 緑泥石と共存することより, 反応 (1) は緑泥石帯中で生 じていたと考えられる.

紅柱石アイソグラッド上の試料は，黒雲母，カリ長石，お 


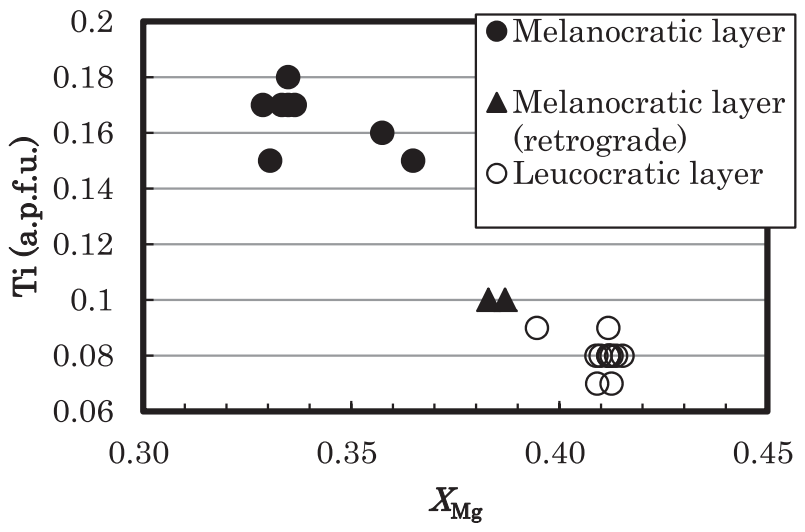

Fig. 8. Ti content (atoms per formula unit) based on 11 oxygens and $X_{\mathrm{Mg}}$ of biotite

よび紅柱石を含む. 石英過剩の岩石中で紅柱石とカリ長石が 共存することは, 白雲母が不安定であることを示唆する. 黒 雲母帯では白雲母は石英と共存しているので, 次のような紅 柱石アイソグラッド反応が考えられる.

$$
\text { 白雲母 }+ \text { 石英 }=\text { 紅柱石 }+ \text { カリ長石 }+ \text { 水 }
$$

しかし, 前述のように, 紅柱石帯の泥質岩中には白雲母が産 する. それらのうち, 紅柱石やカリ長石の包有物として産す る白雲母は, 累進変成作用時に紅柱石やカリ長石が形成され る前に存在していたと考えられる. また，堇青石を置換する 細粒の白雲母集合体は，後退変成作用時に董青石の分解に よって生成したと考えられる. したがって，最高変成作用時 に，石英過剰なマトリクスに安定に存在していたと考えられ る白雲母は確認されていない，このことは反応(2)をアイソ グラッド反応と考えることと矛盾しない。紅柱石帯にみられ る, 黒雲母 + カリ長石 + 紅柱石 + 堇青石の組み合わせは, 反応 (2)より高温で生じる次の連続反応で説明できる.

$$
\text { 紅柱石 }+ \text { 黒雲母 }+ \text { 石英 }=\text { 堇青石 }+ \text { カリ長石 }+ \text { 水 }
$$

この反応は温度が上がると右辺側に進行し, 紅柱石は反応物 となる(Pattison, 1989)．このことは，多くの紅柱石が他形 であることや紅柱石が堇青石の多結晶体に囲まれる組織 (Fig. 4e) と調和的である. 堇青石は紅柱石帯のみに産する ので, 堇青石 + カリ長石の共生関係はこの反応によって生 じたと考えられる.

前述したように, 紅柱石帯中のカリ長石を含む泥質岩に, 白雲母の集合体に囲まれたコランダムがまれに産する. この 産状はコランダムがカリ長石と反応する次の後退変成反応に よって形成されたと考えられる.

$$
\text { カリ長石 }+ \text { コランダム }+ \text { 水 }=\text { 白雲母 }
$$

反応 (4) は反応 (2)より高温で生じる. 反応 (4) は石英に不飽 和な条件で生じるにも関わらず泥質岩にみられることは，局 所的に石英に不飽和な環境が実現していた可能性を示唆する (例えば, 佐脇, 1985).

以上のように，紅柱石帯に見られる鉱物組み合わせが連続
反応 (3) に相当し, 紅柱石帯中の反応組織が累進変成反応 (反 応 (3)) と後退変成反応 (反応 (4)) と解釈された. これら反応 (3)，(4) はいずれも反応 (2)よりも高温で生じる反応であり, 反応 (2)を紅柱石帯のアイソグラッド反応と考えることと調 和的である.

\section{2. 温度圧力条件の見積もり}

ザクロ石の縁部の組成が, 累帯構造が定義する組成トレン ド上で変動することから, 各縁部が累帯構造生成における異 なる時期の組成を保持していることがわかる，黒雲母に富む 部分と接する縁部の化学組成はほぼ同じで, かつ X sps が最 小であることから (Fig. 6), それらは最高変成時まで成長し て平衡に至つたと考えられる. 一方, 石英に富む部分と接す る縁部は途中で成長が止まり, その時の組成を保持したと考 えられる. したがって, 黒雲母に富む部分と接している縁部 が最高変成時の組成を表すと考え, 地質温度圧力計に用い た. 前述のように, ザクロ石は優黒質部に産することから, 優黒質部の黒雲母および斜長石の組成を用いた．優黒質部の 黒雲母の組成変動の一部は後退変成作用時の堇青石の分解に 起因し, Tiに乏しくなる傾向がある. したがって, この後 退変成作用の影響を受けていない黒雲母の組成として, 最も Ti に富む黒雲母の組成を選んだ. 斜長石は核部の組成を用 いた. 最高変成時に平衡と考えられる組成を Table 2 に示 す. ザクロ石の $X \mathrm{sps}$ は 0.29 で, 既存の地質温度計作成に 用いた值よりも高い. 中村 (1996) は $X \mathrm{sps}=0.35 \sim 0.40$ で も Hodges and Spear(1982)の温度計が有効であることを 示している. したがって，これらの組成を Hodges and Spear(1982)のザクロ石-黒雲母地質温度計と Hoisch (1990) のザクロ石-黒雲母-斜長石一石英地質圧力計に適用 させて，紅柱石帯の温度圧力条件を見積もつた.

Hoisch (1990)の鉄端成分の式も, マグネシウム端成分の 式も等しく $560{ }^{\circ} \mathrm{C}, 2.3 \mathrm{kbar}$ を示す. 温度計の誤差から発 生する圧力の誤差は $0.90 \mathrm{kbar}$ である. したがって, $560 \pm$ $50{ }^{\circ} \mathrm{C}, 2.3 \pm 0.90 \mathrm{kbar}$ という温度圧力条件を得た. この温 度圧力条件は紅柱石安定領域で, $\mathrm{H}_{2} \mathrm{O}$ の活動度を 1 とした 場合には白雲母 + 石英の安定領域内である (Fig. 9). 変成 条件が, 白雲母 + 石英の安定領域内にあることは, 紅柱石 アイソグラッド反応の議論と矛盾する. 1 つの可能性として, 泥質岩中に炭質物が含まれることから変成流体の組成が純粋 な $\mathrm{H}_{2} \mathrm{O}$ でなかったことが挙げられる. 例えば $X_{\mathrm{H}_{2} \mathrm{O}}=0.4$ の 場合 (Holdaway and Lee, 1977), 見積られた温度圧力条件 は, 白雲母 + 石英の不安定領域内に入り, 結論との矛盾は 解消される (Fig. 9). また, 反応 (2)にアルバイトを加えた 反応 $($ 白雲母 + アルバイト + 石英 $=$ アルミナ珪酸塩 + カリ 長石 $\left.+\mathrm{H}_{2} \mathrm{O}\right)$ は, $X_{\mathrm{H}_{2} \mathrm{O}}=0.6$ の時にこの温度圧力条件で生じ る (Johannes and Holtz, 1996).

\section{3. 上昇過程}

推定した変成反応 (1), (2), （3）はこの順に生じる温度が 高くなる. したがって, 変成温度は北に向かって上昇してお り，この傾向は井上 (1957)の結論を支持する. このことは, 北部と南東部に貫入している花崗岩体のうち, 北部に貫入し た朝倉花崗閃緑岩が調查地域の温度構造を支配する熱源であ 
Table 2. Garnet (rim in contact with biotite), plagioclase (core), and biotite (matrix) compositions within sample K109; garnet, plagioclase, and biotite formulae are calculated using 12, 8, and 11 oxygens, respectively. - : not detected.

\begin{tabular}{|c|c|c|c|}
\hline Mineral & Grt & $\mathrm{Pl}$ & $\mathrm{Bt}$ \\
\hline $\mathrm{SiO}_{2}$ & 36.38 & 60.72 & 33.54 \\
\hline $\mathrm{TiO}_{2}$ & - & - & 2.96 \\
\hline $\mathrm{Al}_{2} \mathrm{O}_{3}$ & 20.34 & 24.20 & 19.16 \\
\hline $\mathrm{FeO}$ & 27.93 & - & 22.36 \\
\hline $\mathrm{MnO}$ & 12.64 & - & 0.79 \\
\hline $\mathrm{MgO}$ & 1.31 & - & 6.30 \\
\hline $\mathrm{CaO}$ & 1.14 & 5.51 & - \\
\hline $\mathrm{Na}_{2} \mathrm{O}$ & - & 8.76 & - \\
\hline $\mathrm{K}_{2} \mathrm{O}$ & - & 0.10 & 8.59 \\
\hline Total & 99.74 & 99.29 & 93.70 \\
\hline $\mathrm{Si}$ & 2.99 & 2.72 & 2.64 \\
\hline $\mathrm{Ti}$ & & & 0.18 \\
\hline $\mathrm{Al}$ & 1.97 & 1.28 & 1.78 \\
\hline $\mathrm{Fe}$ & 1.92 & & 1.47 \\
\hline $\mathrm{Mn}$ & 0.88 & & 0.05 \\
\hline $\mathrm{Mg}$ & 0.16 & & 0.74 \\
\hline $\mathrm{Ca}$ & 0.10 & 0.26 & \\
\hline $\mathrm{Na}$ & & 0.76 & \\
\hline $\mathrm{K}$ & & 0.01 & 0.86 \\
\hline Total & 8.02 & 5.03 & 7.72 \\
\hline
\end{tabular}

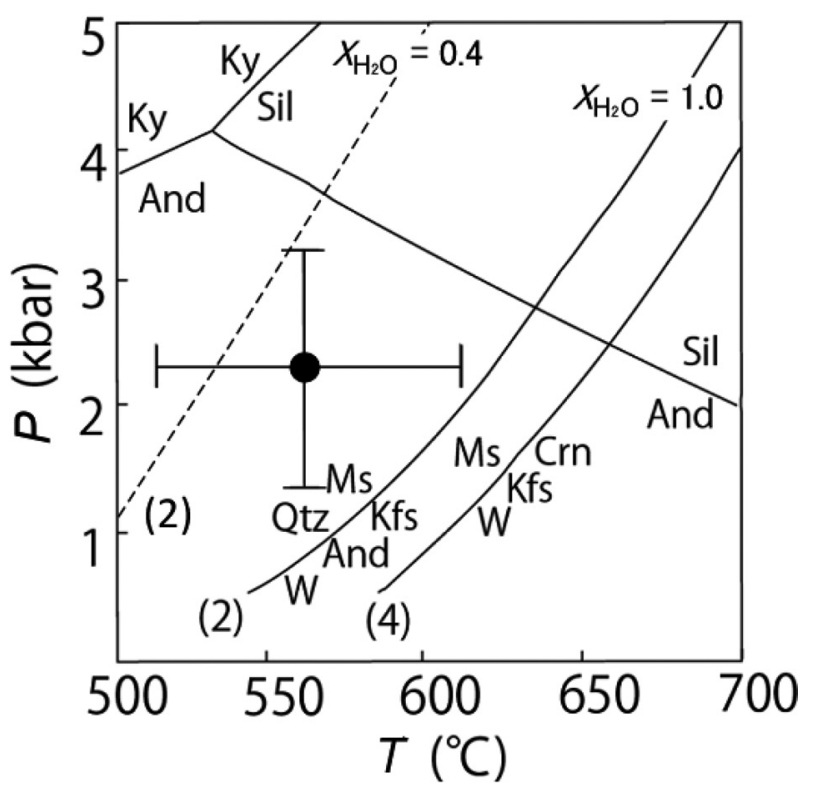

Fig. 9. Pressure-temperature diagram indicating the metamorphic conditions recorded by sample K109; phase diagram for $\mathrm{Al}_{2} \mathrm{SiO}_{5}$ polymorphs is after Bohlen et al. (1991), reactions (2) and (4) at $X_{\mathrm{H}_{2} \mathrm{O}}=1.0$ are after Pattison (1989), and reaction (2) at $X_{\mathrm{H}_{2} \mathrm{O}}=0.4$, shown as a broken line, is after Holdaway and Lee (1977). Abbreviations are as for Fig. 2, with the addition of Ky, kyanite; and Sil, sillimanite.
ることを示唆する.

今回得られた変成圧力は, 地殼の密度を $2700 \mathrm{~kg} / \mathrm{m}^{3}$ と仮 定すると, 深さ約 $9 \mathrm{~km}$ に相当する. つまり，230～160 Ma に高圧の変成作用を受けた周防変成岩類は，本地域では少な くとも $95 \mathrm{Ma}$ (村上, 1989) までに地下約 $9 \mathrm{~km}$ まで上昇し たと考えられる. さらに, 直方層群に覆われることから, 遅 くとも $44 \mathrm{Ma}$ (尾崎・濱崎, 1991)には地表に達していたこ ともわかった.

北部九州の周防変成岩類は, ほぼ同時期の白亜紀花崗岩類 による接触変成作用を被っている. 本研究の北東には平尾花 崗閃緑岩 (黒雲母 $\mathrm{K}-\mathrm{Ar}$ 年代 $91.7 \pm 4.6 \mathrm{Ma}$, 村上, 1989), 南西には玉名花崗閃緑岩 (黒雲母 $\mathrm{K}-\mathrm{Ar}$ 年代 $99.7 \pm 2.5 \mathrm{Ma}$, 富田ほか, 2008) が貫入し, その接触変成条件はそれぞれ約 $700{ }^{\circ} \mathrm{C}, 3 \mathrm{kbar}$ 以下 (Fukuyama et al., 2004), $700{ }^{\circ} \mathrm{C}$ 前 後, 4〜6 kbar(富田ほか, 2008) と見積もられている. 本研 究の成果と合わせると, 周防変成岩類は約 $95 \mathrm{Ma}$ までに南 西部より北東部の方が, より浅所に達していたことが示唆さ れる.

$$
\text { ま と め }
$$

調査地域の周防変成岩類は泥質岩を用いて変成分帯され, 北へ向かって変成度が上昇することがわかった．そのうちの 最高変成度地域の変成条件は $560 \pm 50{ }^{\circ} \mathrm{C}, 2.3 \pm 0.90 \mathrm{kbar}$ と見積もられた. この条件は水の分圧が低い変成流体 $\left(X_{\mathrm{H}_{2} \mathrm{O}}\right.$ $=0.4 \sim 0.6)$ を想定すると, この帯で生じる変成反応の条件 と矛盾しない. この変成圧力は深さ約 $9 \mathrm{~km}$ に相当し, 熱源 と考えられる朝倉花崗閃緑岩の冷却年代の $95 \mathrm{Ma}$ にはこの 深さに達していたことが推定される. その年代に北部九州の 周防変成岩類は, 南西部よりも北東部の方がより浅所に達し ていたと考えられる.

謝辞

本研究は河上哲生氏と宮崎一博氏に查読していただき，有 益なコメントをいただいた. また, 故松本達郎名誉教授のご 寄付による高千穂奨学資金を助成して頂いた. 以上の方々に 厚く御礼申し上げます.

\section{文献}

Bohlen, S. R., Montana, A. and Kerrick, D. M., 1991, Precise determinations of the equilibria kyanite $\cdot$ sillimanite and kyanite $\cdot$ andalusite and a revised triple point for $\mathrm{Al}_{2} \mathrm{SiO}_{5}$ polymorphs. Amer. Mineral., 76, 677-680.

Fukuyama, M., Urata, K. and Nishiyama, T., 2004, Geology and petrology of the Hirao Limestone and the Tagawa metamorphic rocks-with special reference to the contact metamorphism by Cretaceous granodiorite. Jour. Mineral. Petrol. Sci., 99, 25-41.

Hodges, K. V. and Spear, F. S., 1982, Geothermometry, geobarometry and the Al2SiO5 triple point at Mt. Moosilauke, New Hampshire. Amer. Mineral., 67, 1118-1134.

Hoisch, T. D., 1990, Empirical calibration of six geobarometers for the mineral assemblage quartz + muscovite + biotite + plagioclase + garnet. Contrib. Mineral. Petrol., 104, 225234.

Holdaway, M. J. and Lee, S. M., 1977, Fe-Mg cordierite stabili- 
ty in high grade pelitic rocks based on experimental, theoretical, and natural observations. Contrib. Mineral. Petrol., 63, 175-198.

井上 保 (Inoue, T.) , 1957, 朝倉変成岩地域の地質岩石概報. 福岡学 芸大学紀要(理科) (Bull. Fukuoka Gakugei Univ., Sci.), 3, 55-61.

Johannes, W. and Holtz, F., 1996, Petrogenesis and Experimental Petrology of Granitic Rocks. Springer-Verlag, Berlin, 335p.

唐木田芳文・早坂祥三・長谷義隆 (Karakida, Y., Hayasaka, S. and Hase, Y.) , 1992, 第 2 章 中・古生界, 2.9. 白亜紀深成岩類, (2) 北部九州. 日本の地質「九州地方」編集委員会編, 日本の地質 9 九 州地方 (Regional Geology of Japan, Part 9: Kyushu), 共立出 版 (Kyoritsu Shuppan), 86-88.

唐木田芳文・富田 達・松本達郎 (Karakida, Y., Tomita, T. and Matsumoto, T.), 1962, 北九州花崗岩類の $2 \cdot 3$ の問題. 地質雑 (Jour. Geol. Soc. Japan.), 68, 373-376.

久保和也 - 松浦浩久 - 尾崎正紀 - 牧本 博 - 星住英夫 - 鎌田耕太郎 広島俊男 (Kubo, K., Matsuura, H., Ozaki, M., Makimoto, H., Hoshizumi, H., Kamada, K. and Hiroshima, T.), 1993, 福岡 地域の地質. 地域地質研究報告 (20万分の 1 地質図幅) (Geology of the Fukuoka District. With Geological Sheet Map at 1: 200,000), 地質調査所 (Geol. Surv. Japan).

松本達郎 (Matsumoto, T.), 1958, 筑紫山地変成岩地域の地質. 鈴木 醇教授還暦記念論文集 (Mem. Vol. Prof. Suzukis 60th birthday), 141-161.

村上允英 (Murakami, N.)，1989，北九州地域産白亜紀花崗岩類の放 射年代に関する 2,3 の新資料. 別府大学紀要 (Bull. Beppu Univ.), 30, 10-17.

村上允英 - 藤本重美 (Murakami, N. and Fujimoto, S.), 1957, 北九 州田川変成帯南部の地質及び岩石. 岩石鉱物鉱床学会誌 (Jour. Japan. Assoc. Mineral. Petrol. Econ. Geol.), 41, 164-171.

中村大輔 (Nakamura, D.), 1996, ザクロ石-黒雲母温度計について 一三波川変成岩と大文字接触変成岩への適応とその評価一，岩 鉱(Jour. Mineral. Petrol. Econ. Geol.), 91, 165-176.
Nishimura, Y., 1998, Geotectonic subdivision and areal extent of the Sangun belt, Inner Zone of Southwest Japan. Jour. Metamorphic Geol., 16, 129-140.

小山内康人 - 正尾 敏 - 加々美寛雄 (Osanai, Y., Masao, S. and Kagami, H.), 1993, 中部九州内帯花崗岩類の Rb-Sr 全岩アイソク ロン年代. 地質学論集 (Mem. Geol. Soc. Japan), no. 42, 135150.

尾崎正紀・濱崎聡志 (Ozaki, M. and Hamasaki, S.), 1991, 福岡県 北部に分布する古第三系のフィッション・トラック年代. 地質 雜 (Jour. Geol. Soc. Japan), 97, 251-254.

Pattison, D. R. M., 1989, P-T Conditions and the Influence of Graphite on Pelitic Phase Relations in the Ballachulish Aureole, Scotland. Jour. Petrol., 30, 1219-1244.

佐脇貴幸 (Sawaki, T.), 1985, 山口県防府地域に分布する含コランダ ム泥質ホルンフェルス. 地質雑(Jour. Geol. Soc. Japan), 91, 719-722.

富田宰臣・下山正一・松浦浩久・宮崎一博・石橋 毅・三木 孝(Tomita, S., Shimoyama, S., Matsuura, K., Ishibashi, K. and Miki, T.) , 2008, 第 2 章 地質概説, 第 3 章 周防変成コンプレッ クス, 第 4 章 白带紀高温低圧型重複変成領域, 大牟田地域の地質, 地域地質研究報告 (5 万分の 1 図幅) (Geology of the Omuta District. Quadrangle Series, 1:50,000), 産総研地質調査総合 センター(Geol. Surv. Japan, AIST.), 6-13.

Wang, G. F., Banno, S. and Takeuchi, K., 1986, Reactions to define the biotite isograd in the Ryoke metamorphic belt, Kii Peninsula, Japan. Contrib. Mineral. Petrol., 93, 9-17.

渡辺光一郎・林 正雄・ 英彦山団研グループ (Watanabe, K., Hayashi, M. and Hikosan Collaborative Research Group.), 1986, 九州北部 , 英彦山地域に分布する火山岩類のフィッション・ト ラック年代. 地質雑(Jour. Geol. Soc. Japan), 92, 219-230.

山田直利 (Yamada, N.), 1972, 鳥取-大原地域の三郡変成岩類. 地 調月報(Bull. Geol. Surv. Japan), 23, 525-537.

\section{（要 旨）}

北野一平 · 池田 剛, 2012 , 朝倉地域に産する周防変成岩類の接触変成作用の温度圧力条 件一上昇過程の制約一。地質雑， 118，801-809. （Kitano, I. and Ikeda, T., 2012, Pressure and temperature conditions of contact metamorphism of the Suo metamorphic rocks in Asakura area, Fukuoka Prefecture, Japan: constraints on uplifting process. Jour. Geol. Soc. Japan, 118, 801-809.)

福岡県朝倉地域に産する周防変成岩類は白亜紀に接触変成作用を被つている. この接触 変成帯は泥質岩の鉱物組み合わせを用いて, 南から北へ緑泥石帯, 緑泥石一黒雲母帯, 黒雲 母帯, 紅柱石帯の 4 帯に分けられた. 紅柱石がカリ長石と共存することより, 紅柱石アイ ソグラッドは次の反応で定義される：白雲母 + 石英 $=$ 紅柱石 + カリ長石 + 水. 紅柱石帯 の変成条件は, ザクロ石一黒雲母地質温度計とザクロ石一黒雲母-斜長石一石英地質圧力計よ り, $560 \pm 50{ }^{\circ} \mathrm{C}, 2.3 \pm 0.90 \mathrm{kbar}$ と推定された. この接触変成作用の熱源を北方の朝倉花 崗閃緑岩と仮定すると, 周防変成岩類は $95 \mathrm{Ma}$ までに深さ約 $9 \mathrm{~km}$ まで上昇しており, 遅 くとも $44 \mathrm{Ma}$ までに地表に達して直方層群に被覆されたと考えられる. 